\title{
URGENSI PEMBELAJARAN BAHASA ARAB BERBASIS LINGKUNGAN DAN PERMAINAN UNTUK MENINGKATAN KUALITAS BACA TULIS AL- QUR'AN PADA MAHASISWA SEMESTER II JURUAN PGMI FAKULTAS AGAMA ISLAM (FAI)UNIVERSITAS MUHAMMADIYAH MATARAM (UMM) TAHUN AKADEMIK 2015/2016
}

\author{
Oleh: Mappanyompa, Mustapa Ali
}

\begin{abstract}
Abstrak
Pembelajaran Bahasa Arab Berbasis Lingkungan dan Permainan untuk Meningkatan Kualitas Baca Tulis Al-Qur'an pada Mahasiswa Semester II Juruan PGMI Fakultas Agama Islam (FAI)Universitas Muhammadiyah Mataram (UMM) Tahun Akademik 2015/2016. Penelitian ini bertujuan untuk meningkatkan kualitas baca-tulis AlQur'an melalui pembelajaran Bahasa Arab yang berbasis lingkungan dan permainan bahasa Arab. Penelitian ini merupakan penelitian tindakan kelas (PTK) yang tertidi atas sembilan kali pertemuan dalam tiga siklus. Penelitian ini menggunakan empat tahap tindakan yaitu perencan, tindakan, observasi dan refleksi. Adapun yang menjadi subyek penelitian adalah Mahasiswa Semester II Juruan PGMI Fakultas Agama Islam (FAI)Universitas Muhammadiyah Mataram yang berjumlah 32 mahasiswa. Teknik pengumpulan data yang digunakan adalah tes dan observasi. Hasil penelitian menunjukkan bahwa kualitas kemampuan baca-tulis al-Qur'an pada Mahasiswa Semester II Juruan PGMI Fakultas Agama Islam (FAI)Universitas Muhammadiyah Mataram Tahun Akademik 2015/2016 berbasis lingkungan dan permainan dapat ditingkatkan. Peningkatan ini dapat dilihat dengan nilai rata-rata minimal 60 dengan ketuntasan klasikal $85 \%$, hal tersebut dapat dilihat pada peningkatan hasil tes kemampuan baca-tulis al-Qur'an siklus I dengan rata-rata 60; dengan ketuntasan klasikal 25\%. Pada siklus II, rata-rata 75.63 dengan presentasi ketuntasan klasikal 78.13\%. Pada siklus III dengan rata-rata $80.90 \%$ dengan presentasi ketuntasan klasikal $93.75 \%$. Sementara hasil observasi kualitas kemampuan mahasiswa dalam baca-tulis al-Qur'an siklus 1 dengan pertemuan I sampai III berada pada kategori cukup baik (CB), sedangkan pada siklus II dengan pertemuan I sampai III meningkat menjadi kategori baik (B). dan adapun pada siklus III pada pertemuan I sampai III meningkat menjadi kategori sangat baik (SB). Hal tersebut dapat dilihat dalam prosetase katagori kemampuan baca-tulis alQur'an mahasiswa siklus I berdasarkan kategorisasi yang berkemampuan tinggi 5 mahasiswa (15.63\%), berkemampuan sedang 10 mahasiswa (31.25\%) dan berkemampuan rendah 17 mahasiswa (53.12\%). Adapun katagori kemampuan baca tulis al-quran mahasiswa pada siklus II berdasarkan katagori yaitu berkemampuan tinggi ada 10 mahasiswa (31.25\%), berkemampuan sedang 17 (53.13\%) dan berkemampuan rendah 5 mahasiswa (15.63\%). Adapun katagori kemampuan baca tulis al-quran mahasiswa pada siklus III berdasarkan katagori yaitu berkemampuan tinggi ada 15 mahasiswa (46.88\%), berkemampuan sedang 15 (46.88\%) dan berkemampuan rendah 2 mahasiswa (6.25\%).
\end{abstract}

Kata Kunci: Pembelajaran,kemampuan, baca-tulis al-Qur'an, lingkungan dan permainan 


\section{A. PENDAHULUAN}

Mata kuliah Basa Arab bagi mahasiswa bukan sekedar mata kuliah yang termasuk dalam SKS yang harus ditempuh dan mendapatkan nilai standar kelulusan dan ketuntasan, dan bukan pula mata kuliah yang sifatnya terpisah dengan mata kuliah yang lain yang berbasis agama, akan tetapi Bahasa Arab adalah matakuliah yang amat penting diketahui dan diperdalam oleh semua mahasiswa terutama bagi mahasiswa PGMI UM Mataram yang nantinya diharapkan sebagai muballig di lingkungan masing-masing setelah lulus menjadi sarjana.

Yakni belajar bahasa Arab berarti balajar al-Qur'an dan belajar al-Qur'an berarti belajar memahami Agama Islam lebih dalam. Sesuai dengan ayat AlQur'an yang diterangkan dalam delapan surat yang membahas tetang keterkaitan bahasa Arab dengan al-Qur'an dari berbagai sudut. Di antaranya tersebut pada QS. Az-Zuhkruf ayat 3:

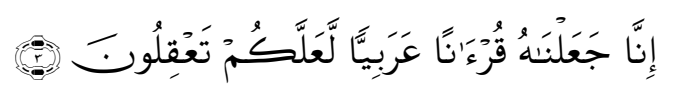

Artinya: Sesungguhnya Kami menjadikan Al Quran dalam bahasa Arab supaya kamu memahami(nya). Q.S. Az-zukhruf: ayat $3{ }^{1}$

Terkait dengan hal tersebut, mahasiswa yang akan menjadi obyek penelitian memiliki latar belakang pendidikan yang berbeda, yaitu dari pendidikan umum SMA dan MA serta SMAK, dengan demikian tidak menutup kemungkinan bahwa kemampuan para mahasiswa khususnya dalam hal baca tulis al-Qur'an akan berbeda-beda. Peningkatan kualitas baca tulis al-Qur'an yang dimaksud adalah bukan sekdar membaca biasa atau menulis biasa melainkan membaca dalam arti memahami isi atau kandungan ayat yang diawali dengan memahami dasar-dasar tarjamah mufradat dan pada tahap berikutnya dapat ditulis dengan bentuk yang sesuai dengan kaidah yang benar.

\footnotetext{
${ }^{1}$ Departemen Agama RI, Al-Qur'an Tajwid dan Terjemahan, 2013. (Bandung: CV. Dipenegoro). HIm.
} 489. 
Berangkat dari keadaan tersebut, peneliti menawarkan pendekatan pembelajaran yang tidak hanya menekankan pada aspek kognitif saja, namun aspek-aspek yang lain untuk melibatkan mahasiswa peran dalam pembelajaran bahasa Arab. Dalam pembelajaran bahasa Arab, khususnya pada kemampuan baca-tulis (qiroah dan kitabah) perlu melibatkan mahasiswa secara langsung agar kemampuan qiraah dan kitabah dirasakan langsung oleh mahasiswa.

Melalui penelitian ini, peneliti merencanakan pembelajaran bahas Arab berbasis lingkungan dan permainan. Lingkungan yang dimaksud adalah lingkungan belajar dengan media yang ada di sekeliling mahasiswa dan apa saja yang dibawa oleh mahasiswa berkaitan dengan perangkat perkuliahan dan permainan dengan menyanyikan lagu anak-anak yang sudah popular akan tetapi dengan nuansa arabiy (sudah dirubah dalam bahasa Arab). Dalam hal ini Mulyasa menyatakan bahwa " pembelajaran dengan pendekatan lingkungan merupakan pembelajaran yang berusaha untuk meningkatkan keterlibatan peserta didik dengan menggunakan lingkungan sebagai sumber belajar". 2 Mahasiswa akan lebih mudah memahami dan menguasai apabila hal-hal yang sedang dipelajarinya dekat dengan kehidupan mereka dan mahasiswa akan lebih tertarik untuk mengetahui apa saja yang melibatkan lingkungan sekitar.

Mulyasa juga menerangkan " menyediakan variasi merupakan keterampilan yang harus dikuasai guru dalam pembelajaran untuk mengatasi kebosanan peserta didik, agar selalu antosias, tekun dan penuh partisipasi", 3 Hal ini perlu dilakukan karena pembelajaran bahasa Arab sangat erat kaitannya dengan al-Qur'an, dan bahasa arab memiki empat point yang akan mendukung kemampuan pemahaman dalam baca tulis al-Qur'an yaitu empat

\footnotetext{
${ }^{2}$ Mel Silbermen, Activ Learning (101 Strategies To Teach Any Subject) ( Assachusetts: Temple University, 1996), hlm 3-4.

${ }^{3}$ Ibid; 3-4.
} 
kemahiran mendengar, mengucapkan, membaca dan menulis. ${ }^{4}$ Dengan demikian diharapkan mahsiswa memiliki produktiv skill dalam bahasa arab dan al-qur'an. ${ }^{5}$ pembelajaran bahasa Arab mahasiswa akan memiliki pengalaman langsung (enative), pengalaman gambar (pictorial), dan pengalaman simbolik tentang ilmu yang akan dipelajari. ${ }^{6}$

Berdasarkan beberapa hal tersebut, pembelajaran bahasa Arab khususnya untuk mahasiswa PGMI perlu dibekali dengan variasi mengajar dalam hal ini adalah permainan bahasa yang merupakan salah satu media pembelajaran bahasa Arab yang sangat menarik bagi peserta didik. Karena peserta didik dituntut untuk berperan aktif dalam melakukan permainan, permainan bahasa ini juga sebagai potret penyatuan dari informasi yang diperoleh melalui indera dengan (audio), indera lihat (visual), dan denar-lihat (audio-visual).

\section{B. PEMBAHASAN}

\section{Pembelajaran}

Pembelajaran memiliki banyak makna tergantung dari sudut pandang keilmuannya. Di antara definisi yang dimaksud adalah kegiatan guru secara terprogram dalam desain instruksional untuk membuat peserta didik belajar secara aktif yang menekankan pada penyediaan sumberbelajar yang dibangun oleh guru dengan pemilihan dan penggunaan metode mengajar yang serasi dengan tujuan pembelajaran dalam rangka pengembangan kreativitas berpikir sehingga peserta didik dapat meningkatkan kemampuan mengkonstruksi pengetahuan baru. Dengan demikian penguasaan terhadap materi simakin maksimal, perubahan perilaku dalam intraksi dengan lingkungannya. ${ }^{7}$

\footnotetext{
${ }^{4}$ Mu'in, Analsis Kontrastif Bahasa Arab dan Bahasa Indonesia, 2004 (Jakarta: Pustaka Husna Baru). HIm, 169

${ }^{5}$ http://www.tesolcourse.com/ tesol-course-article/productive-skill/article-01-ps-php.

${ }^{6}$ Bruner, Tward a Theory of Instruktion,1966 (Cambridge: Harvard Univercity). HIm.10

${ }^{7}$ James Popham, Teknik Mengajar Secara Sistematik, 2001 ( Jakarta: Rineka Cipta), hlm, 141
} 
Dalam sudut pandang dengan desain pembelajaran, bahwa pembelajaran memiliki makna upaya untuk membelajarkan peserta didik, oleh karena itu pembelajaran memusatkan perhatian pada bagaimana membelajarkan siswa bukan pada apa yang dipelajari siswa. Sehingga pembelajaran dapat merubah perilaku peserta didik. Adapun ciri-ciri dari hasil pembelajaran sebagai bentuk perubahan tingkah laku yang tampak di luar adalah perubahan yang disadari, perubahan yang bersifat kontinyu, perubahan yang bersifat fungsional, perubahan yang bersifat positif dan aktif serta perubahan yang bertujuan dan terarah. ${ }^{8}$ Terkait dengan berlangsungnya proses pembelajaran, ada beberapa hal yang perlu dikupas secara teorotis di antaranya yaitu:

a. Metode Pembelajaran

Metode berasal dari bahasa yunani "methodos" dan dalam bahasa arambnya dikenal dengan istilah "torikoh ta'liim” berarti jalan atau cara yang ditempuh. Sehubungan dengan upaya ilmiah, metode pembelajaran menyangkut masalah cara kerja untuk dapat memahami obyek yang menjadi sasaran ilmu yang bersangkutan, dengan kata lain metode pembelajaran sangat erat kaitannya dengan gaya belajar peserta didik dan gaya guru mengajar yang keduanya disingkat menjadi SOLAT (Style of learning and Teaching). ${ }^{9}$ Dan lebih khusus dalam pembelaaran metode diartikan sebagai satu prosedur sebagai alat yang menjadikanmengajar menjadi lebih efektif. ${ }^{10}$

Perlu untuk diketahui bahwa metodologi mengajar memiliki makna yang berbeda dengan metode mengajar. metodologi mengajar adalah ilmu yang mempelajari tentang cara-cara untuk melakukan aktifitas yang tersistem dari sebuah lingkungan yang terdiri dari pendidik dan peserta didik untuk saling berinteraksi dalam melakukan satu kegiatan belajar sehingga proses

\footnotetext{
${ }^{8}$ Winken, Psikologi Pengajaran, 1991 (Jakarata: PT. Grasindo). HIm. 34

${ }^{9}$ Hanafiah Nanang, dkk. Konsep Strategi Pembelajaran, 2009 (Bandung: Reflika Aditama).hlm.41

${ }^{10}$ Wahab dan Aziz, Metode dan Model-Model Mengajar, 2008 (Bandung: Alfabeta). HIm. 36
} 
tersebut berjalan dengan baik dan tujuan pengajaran teracapai. ${ }^{11}$ Sedangkan metode pembelajaran adalah cara pembentukan atau pemantapan pengertian peserta didik atau penerima informasi terhadap suatu penyajian informasi atau bahan ajar. ${ }^{12}$

Jadi pengetahuan tentang metode-metode mengajar sangat diperlukan oleh semua pendidik, sebab berhasil dan tidaknya siswa belajar sangat dipengaruhi pada tepat atau tidaknya metode pembelajaran yang digunakan oleh pendidik. Dapat disimpulakn bahwa metode dalam pembelajaran berfungsi sebagai alat mencapai tujuan pembelajaran yang lebih efektif dan efisien. ${ }^{13}$

b. Ruang lingkup Metode Pembelajaran

Adapun ruang lingkup metode pembelajaran adalah aktualisasinya berwujud serangkaian dari keseluruhan tindakan strategi guru atau dosen dalam rangka mewujudkan kegiatan pembelajaran yang efektif dan efisien. Keseluruhan tindakkan itu sebagai upaya merealisasikan kegiatan pembelajaran mencakup dimensi yang bersifat umum atau khusus. Hal tersebut secara umum sebagai tindakan guru atau dosen adalah : (1). memilih dan mengoprasionalkan tujuan pembelajaran; (2). Memilih dan menetapkan setting pemebelajaran; (3). Pengelolaan bahan ajar, alokasi waktu, metode pembelajaran dan media; (4). Pelaksanaan iklim pembelajaran dan evaluasi.

Keempat hal tersebut aktualisasinya dalam strategi itu sendiri yang sifatnya lebih khusus bertolak dari pengajar itu sendiri sehingga dalam hal ini dibutuhkan guru yang ideal yaitu menguasai materi dengan mendalam, berwawasan luas, komunikatif, menggabungkan teori dan praktek, memiliki variasi pendekatan, bertahap serta tidak menekan dan memaksa. ${ }^{14}$

c. Ciri-ciri Belajar dan Pembelajaran

\footnotetext{
${ }^{11}$ Asmani, Tips Menjadi Guru Inspiratif, Kreatif dan Inivatif, 2009 (Jakarta: DIVAPress). HIm. 139

12 Daryanto, Panduan Proses pembelajaran. 2009. (Jakarta: Publisher). HIm. 388

${ }^{13}$ Daryanto. Panduan Proses Pembelajaran, HIm. 389

${ }^{14}$ Asmani, Tips Menjadi Guru Inspiratif, Kreatif dan Inivatif, HIm. 115
} 
Tanpa disadari, bahwa sebenarnya setiap tindakan pesserta didik dalam kehidupan sehari-hari adalah proses pembelajaran, karena pada hakikatnya belajar itu merupakan interaksi dengan lingkungan. Dimana belajar merupakan kegiatan mental yang tidak dapat disaksikan dari luar, akan tetapi dengan prilaku yang ditunjukkan dapat disimpulkan bahwa anak itu telah belajar.

Sebagaimana diungkapkan oleh Dayton dalam Suarana bahwa manfaat media dalam pembelajaran adalah sebagai berikut: a) jumlah waktu pembelajaran dapat dioptimalkan, b) penyampaian materi pembelajaran dapat diseragamkan, c) peran guru dapat berubah ke arah yang lebih positif dan produktif, d) proses pembelajaran dapat terjadi kapan saja dan dimana saja, dan e) proses pembelajaran dapat menjadi lebih menarik. ${ }^{15}$ Gambar-gambar sangat memperluas situasi stimulus untuk dipelajari. Media dapat menyatakan hal-hal yang sukar disampaikan dengan kata-kata. ${ }^{16}$

\section{Pembelajaran Bahasa Arab dan baca Tulis Al-Qur'an}

Bahasa merupakan bagian yang sangat penting bagi manusia sehingga tiada dapat dipisahkan dari kehidupan manusia itu sendiri. Bahasa itu lahir dari proses produktif (berlangsung pada diri pembicara yang menghasilkan kodekode bahasa yang bermakna dan berguna), dan proses reseptif (berlangsung pada diri pendengar yang menerima kode-kode bahasa yang bermakna dan berguna yang disampaikan oleh pembicara melalui alat artikulasi dan diterima oleh alat pendengaran). ${ }^{17}$

Pembelajaran bahasa Arab pada dasarnya memiliki empat ranah atau kompetensi yang harus dipelajari yaitu: pertama; kompetensi mendengarkan

\footnotetext{
15 Suarana, Pengajaran Mikro, h. 129.

16 Nasution, Berbagai Pendekatan dalam Proses Belajar Mengajar (Jakarta: Rineka Cipta, 2010), h. 196.

${ }^{17}$ Abdul Hamid, Mengukur Kemampuan Bahasa Arab Untuk Studi Islam, 2010. (Malang: UIN Maliki Press). HIm. 42.
} 
(istima'); kedua, kompetensi membaca (Qiroah); ketiga berbicara (kalam); dan keempat kompetensi menulis (kitabah)., penjelasan ke empat kompetensi sebagai berikut:

1. kompetensi mendengarkan (reseptif /istima').

Dalam proses penyerapan pengetahuan, yang paling dahulu berperan dari panca indra kita adalah pendengaran. Bahkan proses transper pengetahuan semenjak anak masih dalam usia kandungan. Pada saat itu panca indra yang lain belum berfungsi. Dalam al-qur'an dijelaskan bahwa urutan pungsi panca indra diawali dari pendengaran, lalu pengelihatan dan diikuti oleh indra yang lain. Dalam al-Qur'an disebutkan bahwa ketika nabi Muhammad diwahyukan agar beliau mendengarkan dahulu firman-firman yang disampaikan dengan penuh hikmat dan merenungi maknanya agar mudah dimengerti maksud dan tujuannya. Dan tidak boleh tergesa-gesa. Dalam surat Toha; 114

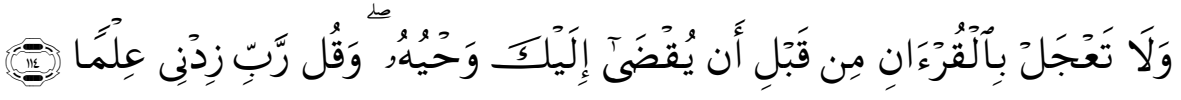

Artinya: dan janganlah engkau (Muhammad) tergesa-gesa membaca alQur'an sebelum selesai diwahyukan kepadamu, dan katakanlah " wahai Tuhanku tambahkanlah ilmu kepadaku”. QS. Toha; $114 .^{18}$

Dalam ayat yang lain juga dikisahkan saat nabi Musa pertama menerima wahyu, dia juga diperintahkan agar mendengarkan dengan baik wahyu yang akan Allah sampaikan kepadanya:

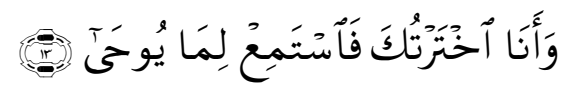

Artinya: Dan Aku (Alloh) telah memilih kamu, Maka dengarkanlah apa yang akan diwahyukan (kepadamu).QS. Toha: 13.

${ }^{18}$ Departemen Agama RI, Al-Qur'an Tajwid dan Terjemahan,. HIm. 320 
2. kompetensi membaca (Qiroah);

kompetensi membaca kata dan kalimat-kalimat arab atau dalam hal ini adalah ayat-ayat dalam al-qur'an adalah sebagai bentuk terapan dari membaca kalimat dalam bahasa arab. Akan tetapi dalam hal ini membaca dalam arti iqra' adalah mengetahui makhraj huruf dengan sempurna, memahami hukum bacaan, serta mengetahui artinya dan memahami tujuan ayat yang terkandung didalamnya. Seperti yang diisyaratkan dalam alqur'an surat al-'alaq ayat pertama:

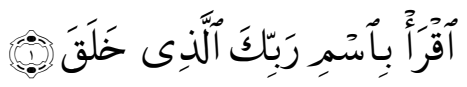

Artinya: bacalah dengan nama Tuhanmu yang maha menjadikan. (QS. Al'Alaq: 1).

Dalam ayat tersebut mengandung makna agar kita membaca semua ciptaan Allah SWT dari diri kita sendiri lalu ke makhluk yang ada di sekeliling kita, dengan demikian kemuliaan Allah akan kita temukan. Bukan sekedar membaca ayat-ayat al-qur'an itu saja, jika sekedar membaca tanpa ada perenungan maknanya maka itu disebut dengan istilah tilawah. Sekedar mengenal makhraj dan hukum bacaan.

3. kompetensi berbicara (kalam);

kompetensi ini pada dasarnya adalah membiasakan mengucapkan kata dan kalimat dalam percakapan menggunakan bahasa Arab. Kompetensi ini akan sangat membantu dalam penyampaian ayat-ayat al-qur'an tatkala berkhutbah atau mengungkapkan dalil yang bersumber dari al-qur'an atau al-hadis. Seperti sabda Rosululloh :

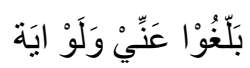

Artinya: Sampaikanlah apa yang kalaian dengar dari aku walaupun satu ayat saja. 
Dan pada dasarnya orang yang menyampaikan pikirannya di depan umum, sejatinya ia sedang mengajar dirinya sendiri. ${ }^{19}$

4. kompetensi menulis (kitabah).,

kompetensi ini adalah keahlian dalam menyambung huruf dengan huruf yang lain yang sangat berguna saat menyampaikan dalil dalam bentuk tulisan yang digunakan sebagai media pembelajaran. Dengan keindahan tulisan arab dan sesuai kaidah (khat imlak), akan menjadi penarik perhatian bagi peserta didik.

Kompetensi ini sangat penting untuk dikuasai oleh seoarang guru yang berorientasi pada ilmu-ilmu keislaman dan bahasa Arab secara umum. Dan cara yang paling efektif untuk mengingat kembali pelajaran yang diterima adalah dengan menulisnya kembali dengan bahasa sendiri, dan pada saat itulah sedang terjadi proses pembelajaran pada diri seseorang. ${ }^{20} \mathrm{Di}$ samping itu, menulis merupakan suatu keterampilan berbahasa yang digunakan untuk berkomunikasi secara tidak langsung, tidak secara tatap muka dengan orang lain. ${ }^{21}$

3. Lingkungan belajar dan Permainan Bahasa

a. Lingkungan Belajar

Keberhasilan seorang guru dalam mencapai target yang sudah ditentukan dalam RPP ketika berlangsungnya proses pembelajaran tidak terlepas dari lingkungan belajar itu sendiri, lebih-lebih kalau itu adalah pelajaran bahasa yang masih sangat asing bagi peserta didik, dalam hal ini pelajaran bahasa Arab, sudah barang tentu akan ditemukan banya kesulitan baik bagi siswa atau bagi guru untuk menentukan metode atau media untuk mempermudah pemahaman peserta didik. Dalam hal ini pembelajaran yang berbasis pendekatan lingkungan belajar merupakan

\footnotetext{
${ }^{19}$ Mukhlis amrin, Cara belajar cerdas dan efektif , 2009. (Jogjakarta: Garailmu ). HIm. 63

${ }^{20}$ Mukhlis amrin, Cara belajar cerdas dan efektif. HIm. 66.

${ }^{21}$ Tarigan “ Menulis Suatu Keterampilan Berbahasa",1994. (Bandung: Angkasa).hlm. 3
} 
satu strategi berusaha untuk meningkatkan keterlibatan peserta didik dengan menggunakan lingkungan sebgai sumber belajar, kerena didik akan lebih mudah belajar apabila hal-hal yang dikerjakan atau dipelajari adalah yang dekat dengan kehidupan atau lingkungan mereka. Mahasiswa atau peserta didik akan lebih tertarik untuk mengetahui apa saja yang melibatkan lingkungan sekitar. ${ }^{22}$

Yang dimaksudkan dengan lingkungan belajar dalam hal ini adalah kondisi ruangan belajar, alat-alat sekolah dalam istilah bahasa arabnya adalah "adawatul madrasiyyah" seperti buku tulis, buku ajar, tas, ransel, pensil, papan tulis, penghapus dan lain sebagainya. Semua benda yang tersebut dijadikan sebagai media untuk mempermudah peserta didik dalam hal memngingat apa yang sedang mereka pelajari, dan mereka akan lebih lama mengingatnya. Lebih khususnya dalam kegiatan belajar bahasa Arab tidak terlepas dari media dan metode yang mendukung terciptanya kegiatan pembelajaran yang optimal. ${ }^{23}$ Apabila difahami secara garis besar, bahwa manusia, materi, atau kejadian yang membangun kondisi yang membuat siswa mampu memperoleh pengetahuan, keterampilan atau sikap. Dalam pengertian ini guru, buku teks, dan lingkungan sekolah merupakan media.

b. Permainan Bahasa

Dalam proses pembelajaran terutama dalam rangka persiapan mahasiswa sebagai pendidik di Madrasah Ibtidaiyah (MI), diperlukan adanya pengalaman atau bakat bagi seorang guru untuk menyampaikan pelajaran terutama pelajaran bahasa Arab dengan cara yang menarik, karena pada tahap ini peserta didik yang dihadapi masih anak-anak, oleh sebab itulah guru membutuhkan satu pendekatan yang menarik dan menyenangkan untuk mempermudah dan menarik minat belajar siswa. Hal tersebut dapat disebut

${ }^{22}$ Silbermen, Activ Learning, hlm, 4.

${ }^{23}$ Ahmad Fuad Efendi, Metodologi Pengajaran Bahasa Arab, 2005 (Malang: Al-Misykat). HIm. 40 
sebagai wasilah atau metode sebagai perantara untuk mempermudah proses pemahaman peserta didik dalam menyerap materi yang dipelajari. Mengiat fungsi media pembelajaran khususnya media visual adalah fungsi atensi, fungsi efektif, fungsi kognitif, dan fungsi konprehensif. ${ }^{24}$

Dalam hal ini ada metode belajar dengan pendekatan permainan bahasa. Di antara permainan bahasa yang dapat disugukan oleh seorang guru adalah sebagai berikut:

a. Imatotu al-dars 'Prediction Guide' (tebak pelajaran)

Adalah strategi yang digunakan untuk melibatkan peserta didik dalam proses pembelajaran secara aktiv dari awal sampai akhir. Dengan strategi ini siswa diharapkan lebih perhatian dan penasaran akan materi yang akan disampaikan. Topic yang akan disampaikan sudah ditentukan, setelah itu siswa dikumpulkan dalam beberapa kelompok dan ditugaskan untuk mencari kosa kata dalam kamus yang sesuai dengan materi.

b. Tebakan kata

Permainan ini dapat dilakukan di awal, di tengah bahkan pada akhir pelajan, dengan tujuan untuk menggairahkan semangat belajar siswa ketika siswa terlihat jenuh.

c. Menyusun Kata

Permainan ini bertujuan untuk menguji penguasaan peserta dalam menyusun kalimat secara benar dan sempurna. Dalam hal ini peserta dibgi ke dalam beberapa kelompok selanjutnya dibagikan potongan kertas yang sudah bertulis kalimat, lalu potongan kalimat itu disusun dan pada tahap akhir guru mengumpulkan kalimat tersebut dan memberikan evaluasi.

d. Potongan Kertas

Permaminan ini bertujuan untuk melatih kemampuan berbicara dan membaca dalam satu cerita yang sudah ditentukan. Kisah tersebut sudah dipotong-

\footnotetext{
${ }^{24}$ Arsyad, Dasar-Dasar Penguasaan Bahasa Arab, 2009 (Yogyakarta: Pustaka pelajar).
} 
potong, dan ditulis kembali kedalam satu cerita utuh sesuai dengan materi yang sedang dipelajari.

e. Kosa kata dalam bentuk nyanyian

Pendekatan dengan permainan ini merupakan media sekaligus teknik pembelajaran bahasa Arab untuk anak-anak dan pemula, karena dalam hal ini peserta didik/mahasiswa disiapkan sebagai guru kelas yang nantinya akan bergaul dengan peserta didik di MI. salah satu tujuan yang diharapkan adalah dengan gubahan lagu-lagu anak Indonesia kedalam bahasa Arab antara lain:

- Meningkatkan kemampuan penguasaan kosa kata peserta didik tidak secara langsung dan lebih cepat menguasai artinya.

- Dengan lagu, tempo, ritme, intonasi dan nada yang ada dalam nyanyian tersebut akan membantu siswa membaca dengan lafal yang lebih fasih dan dapat dengan mudah menulisnya kembali.

Di antara lagu-lagu tersebut adalah sebagai berikut:

1. Sayang ibu (ارحم أمَّ)

2. ABC (أب ج)

3. Balonku Ada Lima (خمسة بالونات)

4. Lihat kebunku (انظر بستاني)

5. Dua Mata saya(عينيّ اثنان)

6. Naik Delman(ركوب العربة)

\section{METODE PENELITIAN}

Penelitian ini menggunakan metode penelitian tindakan kelas yang biasa disebut dengan istilah PTK (Classroom Action Rsearch). Dalam penelitian ini melibatkan secara kolaboratif dalam proses pembelajaran, yakni dosen bidang studi bahasa Arab dan dosen bidang studi baca tulis al-qur'an sebagai kolaboratif utama, dan pengamat.

Penelitian dilaksanakan di Jurusan PGMI Mahasiswa semester II fakultas Agama Islam (FAI) tahun akademik 2015/2016. Subyek penelitian ini adalah 
pada mahasiswa berjumlah 32 orang. Sasaran penelitian ini merupakan satu obyek penelitian tindakan kelas yang merupakan sesuatu yang aktif dan dapat dikemas dalam aktivitas pembelajaran sedangkan waktu pelaksanaan penelitian ini dimulai dari tanggal 3 Maret sampai 10 juni 2016 .

Tujuan utama dalam penelitian tindakan kelas adalah untuk meningkatkan kualitas atau perbaikan pembelajaran khususnya dalam kemampuan baca-tulis al-Qur'an yang dilakukan oleh dosen melalui pembelajaran berbasis lingkungan dan permainan. Oleh Karena itu,tujuan penelitian ini adalah meningkatkan pembelajaran bahasa Arab khususnya kemampuan baca-tulis dalam bahasa Arab melalui pembelajaran berbasis lingkungan dan permainan bahasa.

Sasaran penelitian ini merupakan satu obyek penelitian tindakan kelas yang merupakan suatu yang sifatnya aktif dan dapat dikemas dalam aktivitas pembelajaran, bukan obyek yang sifatnya statis. Adapun sasaran dalam penelitian ini adalah: (1) faktor mahasiswa, yaitu kemampuan mahasiswa semester II jurusan PGMI Universitas Muhammadiyah Mataram dalam baca-tulis al-Qur'an melalui pembelajaran berbasis lingkungan dan permainan; (2) proses pelaksanaan kegiatan pembelajaran yaitu bagaimana interaksi antara mahasiswa baca-tulis alQur'an dengan lingkungan belajar dan saat permainan dalam proses berlangsungnya pembelajaran yang berupa hasil kemampuan yang dicapai oleh mahasiswa.

Rancangan model penelitian tindakan kelas yang akan dipakai dalam penelitian ini adalah mengacu pada model spiral atau siklus menurut Kemmis dan Mc Taggart. Dangan tujuan apabila ditemukan kekuarangan atau kelemahan pada awal pelaksanaan tindakan, maka perencanaan dan pelaksanaan tindakan 
perbaikan dapat dilakukan pada siklus berikutnya sampai target yang diharapkan tercapai. ${ }^{25}$

langkah penelitian dilakukan dalam empat tahapan yaitu:

1. Rencana tindakan atau persiapan yaitu dengan mengembangkan fokus penelitian dengan banyak memperhatikan titik lemah dari proses pembelajaran.

2. Pelaksanaan tindakan, dalam hal ini peneliti sebagai pelaksana tindakan dan pengumpul data pembelajaran bahasa arab dalam peningkatan baca tulis al-Qur'an

3. Observasi, dalam hal ini kolaborator melakukan pengamatan dan mendokumentasikan hal-hal yang terjadi guna mengetahui ketercapaian dari pelaksanaan tindakan yang telah dibuat.

4. Refleksi dan evaluasi serta kesimpulan hasil yakni peneliti dan kolaborator mendiskusikan hasil pengamatan selama tindakan berlangsung, kekurangan yang ditemukan dalam siklus sebelumnya sebagai bahan pendukung untuk menyusun rencana pada tindakan berikutnya sampai tercapainya tujuan penelitian dan mendapatkan hasil yang lebih baik dari sebelumnya.

\section{TEMUAN PENELITIAN}

Dalam pelaksanaan penelitian pada siklus I sampai dengan siklus III, setelah dilakukan satu tahap pembelajaran bahasa Arab yang berbasis lingkungan dan permainan bahasa untuk mengetahui kualitas baca tulis al-Qur'an. Lalu diberikan tes untuk mengetahui sejauh mana pencapaian hasil mahasiswa semester II jurusan Pendidikan Guru Madrasah Ibtidaiyah (PGMI) Universitas Muhammadiah Mataram tahun akademik 2015/2016. Hal tersebut dapat dilihat dalam daftar table sebagai berikut:

1. Perolehan nilai pada siklus I, dapat dilihat pada table 2

${ }^{25}$ Mc Taggart, The Action Reseach (A Short Modern history). 1991 (Australia: Deakin Univercity). HIm, 32 
Table 2.

Perolehan Nilai tes menjawab soal pada Siklus I

\begin{tabular}{|c|c|c|c|}
\hline no & Nama & Nilai & Pencapaian \\
\hline 1 & Eni Aswiyanti & 45 & $\mathrm{Bt}$ \\
\hline 2 & Fadlullah Fakhir & 55 & $\mathrm{Bt}$ \\
\hline 3 & Fatmawati & 70 & Tuntas \\
\hline 4 & Muhammad Zaenudin & 65 & \\
\hline 5 & Wahyu Kurniawan & 75 & $\mathrm{~T}$ \\
\hline 6 & Erni Muliani & 50 & $\mathrm{Bt}$ \\
\hline 7 & Esti Meinasti & 55 & $\mathrm{Bt}$ \\
\hline 8 & Fadlillah & 70 & $\mathrm{~T}$ \\
\hline 9 & Nadhila Amalina Hasyyati & 55 & $\mathrm{Bt}$ \\
\hline 10 & Nilwani Maufuroh & 65 & $\mathrm{Bt}$ \\
\hline 11 & Reni Sepriati & 65 & $\mathrm{Bt}$ \\
\hline 12 & Samsul Rasidin & 65 & $\mathrm{Bt}$ \\
\hline 13 & Abdul Kholiq & 65 & $\mathrm{Bt}$ \\
\hline 14 & Arif Hidayatulloh & 60 & $\mathrm{Bt}$ \\
\hline 15 & Imatun Zaeniyah & 70 & $\mathrm{~T}$ \\
\hline 16 & Hariati & 55 & $\mathrm{Bt}$ \\
\hline 17 & Nurmalasari & 70 & $\mathrm{~T}$ \\
\hline 18 & Amanda Dian Fitriah & 70 & $\mathrm{~T}$ \\
\hline 19 & Ika Amelia & 50 & $\mathrm{Bt}$ \\
\hline 20 & Khaerunnisa & 70 & $\mathrm{~T}$ \\
\hline 21 & Masita & 55 & $\mathrm{Bt}$ \\
\hline 22 & Messi Candra Agustin & 50 & $\mathrm{Bt}$ \\
\hline 23 & Metia Nila Agustina & 65 & $\mathrm{Bt}$ \\
\hline 24 & Neti Suryaningsih & 65 & $\mathrm{Bt}$ \\
\hline
\end{tabular}




\begin{tabular}{|l|l|l|l|}
\hline 25 & Nurul Wahidah & 55 & $\mathrm{Bt}$ \\
\hline 26 & Yuyun Apriliani & 50 & $\mathrm{Bt}$ \\
\hline 27 & Yuliati & 50 & $\mathrm{Bt}$ \\
\hline 28 & Indah Fitrianingsih & 70 & $\mathrm{~T}$ \\
\hline 29 & Annisa & 65 & $\mathrm{Bt}$ \\
\hline 30 & Sukrani & 55 & $\mathrm{Bt}$ \\
\hline 31 & Saripudin & 50 & $\mathrm{Bt}$ \\
\hline 32 & Sopan Sofian & 45 & $\mathrm{Bt}$ \\
\hline & & Rata-rata;60. & \\
\hline
\end{tabular}

Keterangan:

Dari hasil nilai rata-rata pada siklus I, menunjukkan bahwa Penelitian ini belum dikatakan tuntas dikarenakan hanya 8 mahasisiswa yang memperoleh nilai tuntas, yakni yang mendapatkan nilai 70 dari tes yang diberikan.

Table 3.

Perolehan Nilai tes menjawab soal pada Siklus II

\begin{tabular}{|l|l|l|l|}
\hline no & Nama & Nilai & Pencapaian \\
\hline 1 & Eni Aswiyanti & 80 & $\mathrm{~T}$ \\
\hline 2 & Fadlullah Fakhir & 70 & $\mathrm{~T}$ \\
\hline 3 & Fatmawati & 85 & $\mathrm{~T}$ \\
\hline 4 & Muhammad Zaenudin & 80 & $\mathrm{~T}$ \\
\hline 5 & Wahyu Kurniawan & 90 & $\mathrm{~T}$ \\
\hline 6 & Erni Muliani & 65 & $\mathrm{Bt}$ \\
\hline 7 & Esti Meinasti & 70 & $\mathrm{~T}$ \\
\hline 8 & Fadlillah & 85 & $\mathrm{~T}$ \\
\hline 9 & Nadhila Amalina Hasyyati & 70 & $\mathrm{~T}$ \\
\hline 10 & Nilwani Maufuroh & 80 & $\mathrm{~T}$ \\
\hline
\end{tabular}




\begin{tabular}{|l|l|l|l|}
\hline 11 & Reni Sepriati & 80 & $\mathrm{~T}$ \\
\hline 12 & Samsul Rasidin & 80 & $\mathrm{~T}$ \\
\hline 13 & Abdul Kholiq & 80 & $\mathrm{~T}$ \\
\hline 14 & Arif Hidayatulloh & 75 & $\mathrm{~T}$ \\
\hline 15 & Imatun Zaeniyah & 85 & $\mathrm{~T}$ \\
\hline 16 & Hariati & 70 & $\mathrm{~T}$ \\
\hline 17 & Nurmalasari & 85 & $\mathrm{~T}$ \\
\hline 18 & Amanda Dian Fitriah & 85 & $\mathrm{~T}$ \\
\hline 19 & Ika Amelia & 65 & $\mathrm{Bt}$ \\
\hline 20 & Khaerunnisa & 85 & $\mathrm{~T}$ \\
\hline 21 & Masita & 70 & $\mathrm{~T}$ \\
\hline 22 & Messi Candra Agustin & 65 & $\mathrm{Bt}$ \\
\hline 23 & Metia Nila Agustina & 80 & $\mathrm{~T}$ \\
\hline 24 & Neti Suryaningsih & 80 & $\mathrm{~T}$ \\
\hline 25 & Nurul Wahidah & 70 & $\mathrm{~T}$ \\
\hline 26 & Yuyun Apriliani & 65 & $\mathrm{Bt}$ \\
\hline 27 & Yuliati & 65 & $\mathrm{Bt}$ \\
\hline 28 & Indah Fitrianingsih & 85 & $\mathrm{~T}$ \\
\hline 29 & Annisa & 80 & $\mathrm{~T}$ \\
\hline 30 & Sukrani & 70 & $\mathrm{~T}$ \\
\hline 31 & Saripudin & 65 & $\mathrm{Bt}$ \\
\hline 32 & Sopan Sofian & 60 & $\mathrm{Bt}$ \\
\hline & Nilai rata-rata klasikal & 75.6 & \\
\hline
\end{tabular}

Keterangan; Pada siklus dua yaitu nilai rata-rata 75.63 dengan presentasi ketuntasan 78.13\% (mahasiswa yang tuntas dari 32 mahasiswa hanya 25 orang, yang tidak tuntas 17 orang). Penelitian ini bisa dikatakan cukup baik karena sudah mendekati ketentuan ketuntasan klasikal yaitu 85\%. 
Table 4.

Perolehan Nilai tes menjawab soal pada Siklus III

\begin{tabular}{|c|c|c|c|}
\hline no & Nama & Nilai & Pencapaian \\
\hline 1 & Eni Aswiyanti & 86 & $\mathrm{~T}$ \\
\hline 2 & Fadlullah Fakhir & 75 & $\mathrm{~T}$ \\
\hline 3 & Fatmawati & 90 & $\mathrm{~T}$ \\
\hline 4 & Muhammad Zaenudin & 85 & $\mathrm{~T}$ \\
\hline 5 & Wahyu Kurniawan & 95 & $\mathrm{~T}$ \\
\hline 6 & Erni Muliani & 70 & $\mathrm{~T}$ \\
\hline 7 & Esti Meinasti & 75 & $\mathrm{~T}$ \\
\hline 8 & Fadlillah & 90 & $\mathrm{~T}$ \\
\hline 9 & Nadhila Amalina Hasyyati & 75 & $\mathrm{~T}$ \\
\hline 10 & Nilwani Maufuroh & 85 & $\mathrm{~T}$ \\
\hline 11 & Reni Sepriati & 86 & $\mathrm{~T}$ \\
\hline 12 & Samsul Rasidin & 85 & $\mathrm{~T}$ \\
\hline 13 & Abdul Kholiq & 86 & $\mathrm{~T}$ \\
\hline 14 & Arif Hidayatulloh & 80 & $\mathrm{~T}$ \\
\hline 15 & Imatun Zaeniyah & 90 & $\mathrm{~T}$ \\
\hline 16 & Hariati & 75 & $\mathrm{~T}$ \\
\hline 17 & Nurmalasari & 90 & $\mathrm{~T}$ \\
\hline 18 & Amanda Dian Fitriah & 90 & $\mathrm{~T}$ \\
\hline 19 & Ika Amelia & 71 & $\mathrm{~T}$ \\
\hline 20 & Khaerunnisa & 90 & $\mathrm{~T}$ \\
\hline 21 & Masita & 75 & $\mathrm{~T}$ \\
\hline 22 & Messi Candra Agustin & 70 & $\mathrm{~T}$ \\
\hline 23 & Metia Nila Agustina & 85 & $\mathrm{~T}$ \\
\hline 24 & Neti Suryaningsih & 90 & $\mathrm{~T}$ \\
\hline
\end{tabular}




\begin{tabular}{|l|l|l|l|}
\hline 25 & Nurul Wahidah & 75 & $\mathrm{~T}$ \\
\hline 26 & Yuyun Apriliani & 70 & $\mathrm{~T}$ \\
\hline 27 & Yuliati & 85 & $\mathrm{~T}$ \\
\hline 28 & Indah Fitrianingsih & 90 & $\mathrm{~T}$ \\
\hline 29 & Annisa & 85 & $\mathrm{~T}$ \\
\hline 30 & Sukrani & 75 & $\mathrm{~T}$ \\
\hline 31 & Saripudin & 66 & $\mathrm{Bt}$ \\
\hline 32 & Sopan Sofian & 67 & Bt \\
\hline & Nilai rata-rata kelasikal & 80,96 & Tuntas \\
\hline
\end{tabular}

Keterangan: Pada siklus tiga ini yaitu nilai rata-rata $80.90 \%$ dengan presentasi ketuntasan $93.75 \%$ (mahasiswa yang tuntas dari 32 mahasiswa hanya 30 orang, yang tidak tuntas 2 orang akan tetapi sudah mencapai pada nilai rata-rata lulus minimal). Penelitian ini bisa dikatakan sangat baik karena sudah melebihi ketuntasan klasikal yaitu $85 \%$.

Pembahasan dari data nilai mahasiswa setelah tes dari siklus satu sampai siklus ke tiga setelah melalui serangkaian proses pembelajaran bahasa Arab berbasis pendekatan lingkungan dan permainan pada mahasiswa semester II jurusan Pendidkian Guru Madrasah Ibtidaiyah Universitas Muhammadiyah Mataram tahun akademik 2015/2016 sebagai berikut:

\section{SIKLUS I}

a) Kendala

Kegiatan pembelajaran pada siklus I tentunya memiliki kendala yang dapat menghambat proses pembelajaran diantaranya adalah kebanyakan mahasiswa yang belum familier dengan bahasa Arab sehingga mereka kurang perhatian dan belum menunjukkan keseriusan dalam belajar, dan pembelajaran di kelas masih kaku, sehingga sebagian besar mahasiswa belum bisa mengeksplor kemampuan baca-tulis al-Qur'an. 


\section{b) Solusi}

Adapun cara yang dilakukan untuk menyelesaikan kendala yang dihadapi yaitu menegaskan kepada mahasiswa agar tidak berputus asa dalam belajar, dan pada dasarnya suatu keahlian membutuhkan proses dan kesabaran, serta mahasiswa tidak malu untuk bertanya apa yang berlum difahami.

c) Hasil Penelitian

Hasil tes kemampuan baca tulis al-quran mahasiswa semester II jurusan PGMI UM Mataram. Pada siklus satu yaitu nilai rata-rata 60 dengan presentasi ketuntasan 25\% (mahasiswa yang tuntas dari 32 mahasiswa hanya 8 orang dan yang tidak tuntas 24 orang). Penelitian ini belum dikatakan tuntas karena masih berada di bawah ketuntasan kelasikal yaitu $85 \%$.

Adapun katagori kemampuan baca tulis al-quran mahasiswa pada siklus satu berdasarkan katagori yaitu yang berkemampuan tinggi ada 5 mahasiswa (15.63\%), berkemampuan sedang 10 mahasiswa $(31.25 \%)$ dan berkemampuan rendah 17 mahasiswa (53.12\%).

Nilai tersebut lebih jelasnya terdapat dalam table 2.

\section{SIKLUS II}

a) Kendala

Pada siklus II, ternyata sudah ada perubahan yang lebih baik dari siklus I, namun ada beberapa mahasiswa yang masih belum faham karena latar belakan pendidikan sewaktu SMP sampai SMA sederajat, dan masih takut untuk mencoba dan lebih aktiv dalam proses pembelajaran

b) Solusi

Pada siklus I peneliti melakukan refleksi, dari refleksi tersebut tentunya ada tindakan lanjutan pada siklus dua sesuai dengan kondisi mahasiswa, dengan memberikan pendekatan pada latihan dan permainan bahasa tentunya agar mahasiswa lebih rileks santai dalam proses pembelajaran, 
dan memberikan pemahaman dan motivasi akan pentingnya memahami bahasa arab, terutama kamampuan baca-tulis.

c) Hasil Penelitian

Pada siklus dua yaitu nilai rata-rata 75.63 dengan presentasi ketuntasan 78.13\% (mahasiswa yang tuntas dari 32 mahasiswa hanya 25 orang, yang tidak tuntas 17 orang). Penelitian ini bisa dikatakan cukup baik karena sudah mendekati ketentuan ketuntasan klasikal yaitu $85 \%$.

Adapun katagori kemampuan baca tulis al-quran mahasiswa pada siklus dua berdasarkan katagori yaitu berkemampuan tinggi ada 10 mahasiswa (31.25\%), berkemampuan sedang 17 (53.13\%) dan berkemampuan rendah 5 mahasiswa (15.63\%). Nilai tersebut dapat dilihat pada table 3.

\section{SIKLUS III}

a) Kendala

Pada siklus ini masih ada sedikit kendala pada kemahiran yang mendekati nilai dan kemampuan yang diharapkan. Dan dalam hal ini mahasiswa sudah terbiasa bembaca, menulis dalam bahasa arab dengan makhraj huruf dan kaidan penulisan yang baik dan benar.

b) Solusi

Adapun solusi yang dilakukan dari refleksi pada siklus dua adalah dengan memperbanyak tugas mahasiswa baik di rumah atau saat pembelajaran dengan menggunakan media al-Qur'an dan terjemahan tatkala mereka mencari beberapa contoh kalimat sederhana dan langsung menulisnya. Karena pada dasarnya banyak mahasiswa yang sudah bisa membaca alQur'an akan tetapi belum memahami bentuk kata beserta antinya, dan disertakan dengan menyanyikan lagu dalam bahasa arab untuk menghidupkan suasana belajar.

c) Hasil penelitian

Pada siklus tiga ini yaitu nilai rata-rata $80.90 \%$ dengan presentasi ketuntasan $93.75 \%$ (mahasiswa yang tuntas dari 32 mahasiswa hanya 30 
orang, yang tidak tuntas 2 orang). Penelitian ini bisa dikatakan sangat baik karena sudah melebihi ketuntasan klasikal yaitu $85 \%$.

Adapun katagori kemampuan baca tulis al-quran mahasiswa pada siklus tiga berdasarkan katagori yaitu berkemampuan tingga ada 15 mahasiswa (46.88\%), berkemampuan sedang 15 (46.88\%) dan berkemampuan rendah 2 mahasiswa (6.25\%). Nilai tersebut dapat dilihat pada table 4.

Berdasarkan hasil penelitian tiap-tiap siklus yaitu dari siklus satu sampai tiga, menunjukkan bahwa melalui pembelajaran bahasa Arab berbasis lingkungan dan permainan dapat meningkatkan kualitas kemampuan baca-tulis al-Qur'an mahasiswa semester II Jurusan PGMI fakultas Agama Islam (FAI) Universitas Muhammadiyah Mataram tahun akademik 2015/2016.

\section{E. SIMPULAN}

Berdasarkan hasil penelitian tiap-tiap siklus yaitu dari siklus satu sampai tiga, menunjukkan bahwa melalui pembelajaran bahasa Arab berbasis lingkungan dan permainan dapat meningkatkan kualitas kemampuan baca-tulis al-Qur'an mahasiswa semester II Jurusan PGMI fakultas Agama Islam (FAI) Universitas Muhammadiyah Mataram tahun akademik 2015/2016. Hal ini dapat dilihat dari perubahan pencapaian hasil belajar mahasiswa dalam kemampuan baca-tulis alQur'an. Pada Hasil tes kemampuan baca tulis al-quran mahasiswa semester II jurusan PGMI UM Mataram.

Pada siklus satu yaitu nilai rata-rata 60 dengan presentasi ketuntasan $25 \%$ (mahasiswa yang tuntas dari 32 mahasiswa hanya 8 orang dan yang tidak tuntas 24 orang). Penelitian ini belum dikatakan tuntas karena masih berada di bawah ketuntasan kelasikal yaitu 85\%. Adapun katagori kemampuan baca tulis alquran mahasiswa pada siklus satu berdasarkan katagori yaitu yang berkemampuan tinggi ada 5 mahasiswa (15.63\%), berkemampuan sedang 10 mahasiswa (31.25\%) dan berkemampuan rendah 17 mahasiswa (53.12\%). 
Pada siklus II yaitu nilai rata-rata 75.63 dengan presentasi ketuntasan $78.13 \%$ (mahasiswa yang tuntas dari 32 mahasiswa hanya 25 orang, yang tidak tuntas 17 orang). Penelitian ini bisa dikatakan cukup baik karena sudah mendekati ketentuan ketuntasan klasikal yaitu $85 \%$.

Adapun katagori kemampuan baca tulis al-quran mahasiswa pada siklus dua berdasarkan katagori yaitu berkemampuan tinggi ada 10 mahasiswa (31.25\%), berkemampuan sedang $17(53.13 \%)$ dan berkemampuan rendah 5 mahasiswa $(15.63 \%)$.

Pada siklus III nilai rata-rata $80.90 \%$ dengan presentasi ketuntasan $93.75 \%$ (mahasiswa yang tuntas dari 32 mahasiswa hanya 30 orang, yang tidak tuntas 2 orang). Penelitian ini bisa dikatakan sangat baik karena sudah melebihi ketuntasan klasikal yaitu $85 \%$.

Adapun katagori kemampuan baca tulis al-quran mahasiswa pada siklus tiga berdasarkan katagori yaitu berkemampuan tingga ada 15 mahasiswa (46.88\%), berkemampuan sedang $15(46.88 \%)$ dan berkemampuan rendah 2 mahasiswa $(6.25 \%)$.

\section{DAFTAR PUSTAKA}

Abdul Hamid, 2010. Mengukur Kemampuan Bahasa Arab Untuk Studi Islam, (Malang: UIN Maliki Press).

Ahmad Fuad Efendi, 2005, Metodologi Pengajaran Bahasa Arab, (Malang: AlMisykat).

Arsyad, 2009, Dasar-Dasar Penguasaan Bahasa Arab, (Yogyakarta: Pustaka pelajar).

Asmani, 2009. Tips Menjadi Guru Inspiratif, Kreatif dan Inivatif,. (Jakarta: DIVAPress).

Bruner, 1966. Tward a Theory of Instruktion, (Cambridge: Harvard Univercity).

Daryanto. 2009. Panduan Proses Pembelajaran, (Jakarta: Publisher). 
Departemen Agama RI, 2013. Al-Qur'an Tajwid dan Terjemahan, (Bandung: CV. Dipenegoro).

Mukhlis amrin, , 2009. Cara belajar cerdas dan efektif (Jogjakarta: Garailmu ).

Hanafiah Nanang, dkk. 2009. Konsep Strategi Pembelajaran, (Bandung: Reflika Aditama).

James Popham, 2001. Teknik Mengajar Secara Sistematik, ( Jakarta: Rineka Cipta).

Mc Taggart, 1991. The Action Reseach (A Short Modern history), (Australia: Deakin Univercity).

Mel Silbermen, Activ Learning (101 Strategies To Teach Any Subject) ( Assachusetts: Temple University, 1996).

Silbermen, 1996. Activ Learning (101 Strategies To Teach Any Subject Assachusetts: Temple University).

Mu'in, 2004. Analsis Kontrastif Bahasa Arab dan Bahasa Indonesia, (Jakarta: Pustaka Husna Baru).

Ridwan, 2009. Metode dan teknik Penyusunan Proposal Penelitian, (Bandung: Alpabeta).

Tarigan, 1994. Menulis Suatu Keterampilan Berbahasa, (Bandung: Angkasa).

Wahab dan Aziz, Metode dan Model-Model Mengajar, (Bandung: Alfabeta).

Winken, 1991. Psikologi Pengajaran, (Jakarata: PT. Grasindo).

http://www.tesolcourse.com/ tesol-course-article/productive-skill/article-01-ps-php. 